\title{
KESADARAN DAN KEPATUHAN HUKUM TERHADAP PENERAPAN PROTOKOL KESEHATAN MASA PANDEMI COVID-19 DI UPBJJ UT SAMARINDA
}

\author{
Megafury Apriandhini ${ }^{1}$, Yeni Santi ${ }^{2}$, Ernayanti Nur Widhi ${ }^{3}$ \\ ${ }^{1,2}$ Program Studi Ilmu Hukum, FHISIP, Universitas Terbuka \\ e-mail: megafury@ecampus.ut.ac.id, yenisanti@ecampus.ut.ac.id \\ ${ }^{3}$ Prodi Pendidikan Guru Anak Usia Dini, FKIP, Universitas Terbuka \\ ernayanti.widhi@ecampus.ut.ac.id
}

\begin{tabular}{l}
\hline \multicolumn{1}{c}{ Article Info } \\
\hline Keyword: \\
Legal awareness \\
Legal compliance \\
Workers \\
Covid-19
\end{tabular}

Article Info

Kata Kunci:

Kesadaran hukum

Kepatuhan hukum

Pekerja

Covid-19

\begin{abstract}
This article discusses the application of legal awareness of UPBJJ employees at Samarinda Open University. The problems faced are whether employees have implemented health protocols and whether there is control from the office for the implementation of health protocols at UPBJJ UT Samarinda. This research is a type of empirical research through a sociological approach. The data was collected by using observation techniques, literature study and interviews. The results of this study indicate that workers' awareness and legal compliance with the application of health protocols during the Covid-19 pandemic is very important to be applied in order to break the chain of the spread of Covid-19.

Abstrak
Artikel ini membahas mengenai penerapan kesadaran hukum
pegawai UPBJJ Universitas Terbuka Samarinda. Permasalahan
yang dihadapi adalah apakah pegawai sudah menerapkan
protokol kesehatan dan apakah ada kontrol dari kantor untuk
pelaksanaan protokol kesehatan di UPBJJ UT Samarinda.
Penelitian ini merupakan jenis penelitian empiris melalui
pendekatan sosiologi. Pengumpulan data dilakukan dengan
teknik observasi, study literatur dan wawancara. Hasil penelitian
ini menunjukan bahwa kesadaran dan kepatuhan hukum pekerja
terhadap penerapan protokol kesehatan masa pandemi Covid-19
sangatlah penting untuk diterapkan guna memutus mata rantai
penyebaran Covid-19.
\end{abstract}

\section{Pendahuluan}

Kasus Covid-19 pertama kali dilaporkan terjadi di Indonesia yaitu pada 2 Maret 2020 yang diumumkan oleh Presiden Joko Widodo dimana dua orang warga Indonesia terkonfirmasi terpapar Covid-19. Guna mencegah penyebaran Covid-19 yang lebih luas lagi pemerintah membuat suatu kebijakan tentang Protokol Kesehatan yang wajib diikuti seluruh masyarakat yang ditetapkan oleh Kementrian Kesehatan Republik Indonesia Nomor HK.01.07/MENKES/382/2020 tentang Panduan Pencegahan dan Pengendalian Corona Virus Diase 2019 (Covid-19) di Tempat Kerja Perkantoran dan Industri dalam Mendukung Keberlangsungan Usaha Pada Situasi Pandemi. Aturan ini sebagai salah satu upaya pemerintah untuk dapat dipatuhi masyarakat dalam berkegiatan baik di kantor. Aturan ini diikuti dengan dibuatnya kebijakan baru yang diterbitkan melalui Surat Edaran Menteri 
Pendayagunaan Aparatur Negara dan Reformasi Birokrasi Nomor 58 Tahun 2020 tentang Sistem Kerja Pegawai Aparatur Sipil Negara Dalam Tatanan Normal Baru.

Universitas Terbuka (UT) sebagai perguruan tinggi jarak jauh menempatkan kantor Unit Program Belajar Jarak Jauh Universitas Terbuka-UT (UPBJJ-UT) sebagai wadah informasi mahasiswa yang ada pada setiap daerah. Pada masa pademi Covid-19 dikutip dari Menteri Pendidikan dan Kebudayaan (Mendikbud) Nadiem Anwar melalui siaran PERS Nomor: 137/sipres/A6/VI/2020 mengenai sistem pembelajaran di masa pandemi dengan menggunakan metode pembelajaran secara daring dan mengizinkan aktivitas mahasiswa di kampus jika memenuhi protokol kesehatan dan kebijakan yang dikeluarkan Direktur Jenderal terkait salah satunya mencakup kegiatan akademik/vokasi. Berdasar atas siaran pers tersebut, Universitas Terbuka kemudian mengeluarkan kebijakan melalui Peraturan Rektor Universitas Nomor: 721 Tahun 2020 tentang Kebijakan Layanan Pendidikan Universitas Terbuka dalam Situasi Pandemi Covid-19 Semester 2020/21.2 (2020.2) Tahun 2020. Kebijakan rektor tersebut digunakan sebagai pedoman bagi seluruh penyelenggaraan layanan pendidikan di UT.

Dalam hal penerapan protokol kesehatan di wilayah kantor, UT mengeluarkan Surat Edaran Pengawasan Ketat Protokol Kesehatan dalam Penanganan Corona Virus Diase (Covid-19) di Iingkungan Universitas yaitu SE Nomor 33828/UN31/KP.11.00/2020 tenyang Kewaspadaan Pencegahan Penyebaran Covid-19 di Lingkungan Universitas Terbuka dan SE Nomor 26681/UN31.BKUK/HM/02/2021 dalam rangka menanggulangi penyebaran Covid-19 yang masih terus berlanjut di seluruh daerah Indonesia.

UPBJJ UT Samarinda sebagai unit pelaksanaan dan pelayanan kepada mahasiswa menerapkan protokol kesehatan berdasarkan surat edaran yang dikeluarkan oleh Universitas Terbuka. Walau seluruh pegawai diharuskan untuk work fro Office (WfO) selama hari kerja, para pegawai tetap patuh terhadap protokol kesehatan yang diterapkan oleh UPBJJ-UT Samarinda. Hal ini terbukti dari kecilnya jumlah pegawai yang terpapar Covid-19 yaitu sebanyak dua orang, dari tahun 2020 sampai 2021 awal. Dari kedua kasus tersebut bukan berasal dari kluster kantor melainkan klaster keluarga,

Melalui kejadian ini, pentingnya kesadaran dan kepatuhan protokol kesehatan tidak hanya di lingkungan kerja saja, tetapi penting adanya kesadaran dan kepatuhan masyarakat di lingkungan masyarakat dan keluarga. Karena, walaupun para pekerja di suatu instansi telah menerapkan protokol kesehatan ketika bekerja namun dapat saja tertular dari faktor luar semisal dari keluarga yang tidak mematuhi protokol kesehatan sesuai dengan SE Nomor HK.01.07/MENKES/382/2020 tentang Protokol Kesehatan Bagi Masyarakat di Tempat dan Fasilitas Umum dalam Rangka Pencegahan dan Pengendalian Corona Virus Disease 2019 (Covid-19).

Kesadaran hukum akan aturan yang diberikan oleh pemerintah merupakan suatu hal yang sangat penting sebagai upaya kita mencegah penyebaran Covid-19 karena dengan perilaku sadar hukum kita sebagai masyarakat artinya turut berperan mendukung pemerintah menurunkan angka penyebaran Covid-19 yang lebih luas. Hal inilah yang menjadikan kita harus patuh dan sadar pentingnya protokol kesehatan menghindari hal-hal yang menimbulkan efek dalam pekerjaan maupun diluar pekerjaan. Nilai-nilai dalam mentaati dan mematuhi protokol kesehatan tersebut haruslah selalu dijunjung tinggi dan dilaksanakan, sehingga perlu dan pentingnya kesadaran dan kepatuhan hukum terhadap protokol kesehatan yang dilakukan seluruh staf UPBJJ UT Samarinda di masa pandemik sekarang ini dapat mengurangi laju penyebaran Covid-19, dan kita menjadi bagian penting dari pemerintah untuk menerapkan aturan kesehatan dengan penerapan protokol kesehartan masa pandemi. untuk itu peneliti mengambil topik tentang "KESADARAN DAN KEPATUHAN HUKUM TERHADAP PENERAPAN PROTOKOL KESEHATAN MASA PANDEMI COVID-19 DI UPBJJ UT SAMARINDA".

Berdasarkan latar belakang tersebut, rumusan permasalahan dari artikel ini, yaitu kebijakan yang diambil oleh UT dalam rangka menanggulangi pandemi Covid-19, pelaksanaan protokol kesehatan di UPBJJ UT Samarinda, serta kesadaran dan kepatuhan hukum dari para pegawai UPBJJUT Samarinda atas protokol yang diterapkan oleh UT. 


\section{Metode Penelitian}

Artikel ini menggunakan metode penelitian hukum empiris melalui pendekatan efektifitas hukum untuk mengetahui efektifitas dari suatu peraturan. Hasil penelitian ini menunjukkan bahwa dengan kesadaran dan kepatuhan hukum yang dilakukan pekerja terhadap penerapan protokol kesehatan di masa pandemi Covid 19 pada UPBJJ-UT Samarinda dapat mengurangi tingkat penyebaran virus yang lebih besar di kota Samarinda.

\section{Pembahasan \\ Kesadaran Hukum}

Hukum adalah suatu aturan yang mengikat dan harus dipatuhi oleh masyarakat dalam kehidupan sehari-hari. Hukum menuntut kesadaran dari masyarakat untuk dapat dipatuhi. Banyak teori hukum yang dikemukankan oleh para ahli dengan masing-masing pendapat yang mereka jelaskan, seperti yang dijelaskan oleh J.C.T. Simorangkir:

"Hukum itu ialah peraturan-peraturan yang bersifat memaksa, yang menentukan tingkah laku manusia dalam linkungan masyarakat yang dibuat oleh badan-badan resmi yang berwajib pelanggaran mana terhadap peraturan-peraturan tadi berakibat diambilnya tindakan yaitu dengan hukum tertentu” (Yos Johan Utama, 2018:1.4).

Kesadaran dan kepatuhan hukum pada dasarnya merupakan suatu nilai-nilai yang harus dimiliki masyarakat untuk dapat tunduk dan taat terhadap hukum. Menurut Soerjono Soekanto, kesadaran hukum merupakan suatu penilaian terhadap hukum yang ada atau diharapkan" (Dody Saputra Simanjuntak, 2016:4). Menurut Selo Sumarjan, masalah kesadaran hukum berkaitan erat dengan faktor-faktor sebagai berikut.

1. Usaha-usaha menanamkan hukum dalam masyarakat, yaitu menggunakan tenaga manusia, alatalat, organisasi dan metode agar masyarakat mengetahui, menghargai, mengakui, dan mentaati hukum.

2. Reaksi masyarakat yang didasarkan pada sistem nilainilai yang berlaku.

3. Jangka waktu penanaman hukum diharapkan dapat memberikan hasil (H. R. Otje Salman Soemodiningrat, 2009:52).

Prof.Soerjono Soekanto mengemukakan empat indikator kesadaran hukum yang secara beruntun (tahap demi tahap), yaitu sebagai berikut.

1. Pengetahuan tentang hukum merupakan pengetahuan seseorang berkenan dengan perilaku tertentu yang diatur oleh hukum tertulis yakni tentang apa yang dilarang dan apa yang diperbolehkan.

2. Pemahaman tentang hukum adalah sejumlah informasi yang dimiliki oleh seseorang mengenai isi dari aturan (tertulis), yakni mengenai isi, tujuan, dan manfaat dari peraturan tersebut.

3. Sikap terhadap hukum adalah suatu kecenderungan untuk menerima atau menolak hukum karena adanya penghargaan atau keinsyafan bahwa hukum tersebut bermanfaat bagi kehidupan manusia dalam hal ini sudah ada elemen apresiasi terhadap aturan hukum.

4. Perilaku hukum adalah tentang berlaku atau tidaknya suatu aturan hukum dalam masyarakat, jika berlaku suatu aturan hukum, sejauh mana berlakunya itu dan sejauh mana masyarakat mematuhinya (Soerjono Soekanto, 1982:150).

Beberapa faktor yang memengarui masyarakat tidak sadar akan pentingnya hukum adalah sebagai berikut.

1. Adanya ketidak pastian hukum

2. Peraturan-peraturan bersifat statis

3. Tidak efisiennya cara-cara masyarakat untuk mempertahankan peraturan yang berlaku (Rahardjo Satjipto, 1991:112).

Membentuk suatu kesadaran hukum tidaklah mudah, tidak semua masyarakat mampu memiliki sikap kesadaran hukum, untuk itu perlu menanamkan nilai-nilai hukum untuk membentuk kesadaran 
masyarakat sehingga dapat dilaksanakan melalui aturan-aturan yang telah di bentuk sehingga timbul sikap patuh terhadap hukum yang berlaku.

\section{Kepatuhan Hukum}

Perilaku patuh merupakan suatu sikap yang diharapkan dimiliki seseorang atau masyarakat untuk menghindari diri dari suatu perbuatan yang melanggar yang dapat menimbulkan suatu sanksi apabila seseorang atau masyarakat tersebut melakukan kesalahan. Perilaku patuh dapat diawasi dan diarahkan demi terlaksananya kaidah-kaidah hukum yang berlaku.

Ada beberapa faktor yang dapat menyebabkan warga masyarakat memetuhi hukum menurut Soerjono Sukamto, yaitu sebagai berikut.

a. Compliance

"An overt acceptance induced by expectation of rewards and an attempt to avoid possible punishment - not by any conviction in the desirability of the enforced nile. Power of the influencing agent is based on „means-control" and, as a consequence, the influenced person conforms only under surveillance”.

Suatu kepatuhan yang didasarkan pada harapan akan suatu imbalan dan usaha untuk menghindari diri dari hukuman atau sanksi yang mungkin dikenakan apabila seseorang melanggar ketentuan hukum. Kepatuhan ini sama sekali tidak didasarkan pada suatu keyakinan pada tujuan kaidah hukum yang bersangkutan, dan lebih didasarkan pada pengendalian dari pemegang kekuasaan. Sebagai akibatnya, kepatuhan hukum akan ada apabila ada pengawasan yang ketat terhadap pelaksanaan kaidah-kaidah hukum tersebut.

\section{b. Identification}

"An acceptance of a rule not because of its intrinsic value and appeal but because of a person"s desire to maintain membership in a group or relationship with the agent. The source of power is the attractiveness of the relation which the persons enjoy with the group or agent, and his conformity with the rule will be dependent upon the salience of these relationships"

Terjadi bila kepatuhan terhadap kaidah hukum ada bukan karena nilai intrinsiknya, tetapi agar keanggotaan kelompok tetap terjaga serta ada hubungan baik dengan mereka yang diberi wewenang untuk menerapkan kaidah hukum tersebut. Daya tarik untuk patuh adalah keuntungan yang diperoleh dari hubungan-hubungan tersebut. Dengan demikian kepatuhan tergantung pada baik-buruk interaksi.

\section{c. Internalization}

"The acceptance by an individual of a rule or behavior because he finds its content intrinsically rewarding ... the content is congruent with a person "s values either because his values changed and adapted to the inevitable".

Pada tahap ini seseorang mematuhi kaidah hukum karena secara intrinsik kepatuhan tadi mempunyai imbalan. Isi kaidah tersebut adalah sesuai dengan nilai-nilainya dari pribadi yang bersangkutan, atau karena ia mengubah nilai-nilai semula dianutnya. Hasil dari proses tersebut adalah suatu konformitas yang didasarkan pada motivasi secara intrinsik. Titik sentral dari kekuatan proses ini adalah kepercayaan orang tadi terhadap tujuan dari kaidah-kaidah yang bersangkutan, terlepas dari pengaruh atau nilai-nilainya terhadap kelompok atau pemegang kekuasaan maupun pengawasannya. Tahap ini merupakan derajat kepatuhan tertinggi, di mana ketaatan itu timbul karena hukum yang berlaku sesuai dengan nilai-nilai yang dianut berlaku (Rahardjo Satjipto, 1991:11). 
Seseorang lebih cenderung patuh pada hukum yang dianggap sesuai dan konsisten dengan norma-norma mereka. Komitmen normatif melalui moralitas personal (normative commitment through morality) berarti patuh pada hukum karena hukum dianggap suatu keharusan, sedangkan komitmen normatif melalui legitimasi (normative commitment through legitimacy) berarti patuh pada peraturan karena otoritas penyusun hukum yang memiliki hak untuk mendikte perilaku (Rachmat Saleh, 2004:14).

Kepatuhan hukum menjadi sangat penting diterapkan karena banyak aturan maupun kaidah hukum tersebut yang memiliki dampak yang baik dalam kehidupan bermasyarakat. Dengan menerapkan perilaku patuh warga masyarakat menjadi taat didukung dengan kebijakan pemerintah yang memiliki dasar hukum yang jelas dalam menerapkan sanksi dan aturan.

\section{Pekerja}

Pekerja dapat diartikan sebagai pegawai yang bekerja pada suatu badan organisasi maupun instansi disuatu lembaga. Dalam Kamus Besar Bahasa Indonesia Pekerja merupakan panitia yang mengurus pelaksanaan tugas sehari-hari pada suatu organisasi. Sedangkan Pekerja menurut ketentuan umum Pasal 1 Undang-Undang Nomor 13 Tahun 2003 yaitu "Setiap orang yang bekerja dengan menerima upah atau imbalan dalam bentuk lain". Sedangkan menurut Undang-Undang Nomor 21 Tahun 2000 tentang Serikat Pekerja menjelaskan pekerja adalah setiap orang yang bekerja dengan menerima upah atau imbalan dalam bentuk lain.

Pekerja dapat juga dikatakan sebagai tenaga kerja yang dikemukakan oleh Dr. Payaman Simanjuntak memiliki pengertian yang lebih luas dari pekerja/buruh. Pengertian tenaga kerja ini mencakup tenaga kerja/buruh yang sedang terkait dalam suatu hubungan kerja dan tenaga kerja yang belum bekerja. Sedangkan pengertian dari pekerja/buruh adalah setiap orang yang bekerja dengan menerima upah atau imbalan dalam bentuk lain. Dengan kata lain, pekerja atau buruh adalah tenaga kerja yang sedang dalam ikatan hubungan kerja (Hardijan Rusli, 2003: 12). Sedangkan menurut Mulyadi bahwa tenaga kerja (manpower) pada dasarnya adalah penduduk dalam usia kerja (berusia 15-64 tahun) atau jumlah seluruh penduduk dalam suatu negara yang dapat memproduksi barang dan jasa jika ada permintaan terhadap tenaga mereka, dan jika mereka mau berpartisipasi dalam aktivitas tersebut (Subri Mulyadi: 2012: 59).

Pekerja yang dimaksud dalam artikel ini adalah pegawai UPBJJ UT Samarinda yang terdiri dan Pegawai Negeri Sipil (PNS), Pegawai Badan Layanan Umum (BLU), dan Tenaga Kontrak Tahunan (TKT). Berikut ini adalah data pegawai di UPBJJ UT Samarinda.

\begin{tabular}{|c|l|c|}
\hline No. & \multicolumn{1}{|c|}{ Status } & Jumlah \\
\hline 1 & Pegawai Negeri Sipil (PNS) & 14 orang \\
\hline 2 & Pegawai Badan Layanan Umum (BLU) & 1 orang \\
\hline 3 & Tenaga Kontrak Tahunan (TKT) & 24 orang \\
\hline
\end{tabular}

Dari ke-39 pegawai di UPBJJ UT Samarinda memiliki tugas dan kewajiban yang sama, terutama dalam menjalankan protokol kesehatan dalam menaggulangi Covid-19.

\section{Kesadaran dan Kepatuhan Hukum Pekerja terhadap Protokol Kesehatan Masa Pandemi Covid-19 di UPBJJ-UT Samarinda}

Penulisan artikel ini dilakukan melalui beberapa tahapan yaitu dengan mengumpulkan fakta yang terkait kondisi terkini berdasarkan atas bagaimana kesadaran dan kepatuhan hukum perkerja terhadap protokol kesehatan masa pandemi di UPBJJ-UT Samarinda. Dengan adanya aturan protokol kesehatan memiliki tujuan agar masyarakat memiliki kesadaran dan kepatuhan hukum dalam mencegah penyebaran virus yang lebih besar, dan setiap pekerja yang merupakan masyarakat yang ada dilingkungan UPBJJ-UT Samarinda harus mengerti, mematuhi, dan melaksanakan aturan tersebut tanpa terkecuali. 
Berikut ini merupakan data pelaksanaan protokol kesehatan atas kebijakan UT pada UPBJJ UT Samarinda

\begin{tabular}{|c|l|c|}
\hline No. & \multicolumn{1}{|c|}{ Kriteria } & Prosentase \\
\hline 1 & Memakai masker & $100 \%$ \\
\hline 2 & Mencuci tangan dengan menggunakan sabun dan hand sanitizer & $84,62 \%$ \\
\hline 3 & $\begin{array}{l}\text { Petugas keamanan unit wajib mengecek suhu tuhuh pegawai dan } \\
\text { tamu dengan menggunakan thermal gun }\end{array}$ & $76,92 \%$ \\
\hline 4 & $\begin{array}{l}\text { Seluruh petugas kebersihan masuk kerja secara full team dan } \\
\text { diminta membersihkan fasilitas umum, termasuk } \\
\text { menyemprotkan cairan disinfektan pada beberapa sarana kerja } \\
\text { setiap 30 menit sekali }\end{array}$ & $82,05 \%$ \\
\hline 5 & Penyemprotan disinfektan di lingkungan kerja UT secara berkala & 69,23 \\
\hline 6 & Membawa sajadah masing-masing ketika beribadah di musholla & $64,1 \%$ \\
\hline 7 & Menyemprot cairan disinfektan ketika naik bis UT & $0 \%$ \\
\hline
\end{tabular}

Berdasarkan pada pengumpulan data yang dilakukan pada perilaku pegawai UPBJJ UT Samarinda dalam menerapkan sikap patuh akan protokol kesehatan yang sudah dikeluarkan oleh UT secara keseluruhan atau 100\% sudah menggunakan masker. Sebagian besar mencuci tangan dengan menggunakan sabun dan hand sanitizer serta membersihkan fasilitas umum, termasuk menyemprotkan cairan disinfektan pada beberapa sarana kerja setiap 30 menit sekali. Selain kewajiban yang dilakukan oleh individual, Kantor UPBJJ UT Samarinda juga harus menugaskan petugas yang wajib mengecek suhu tuhuh pegawai dan tamu dengan menggunakan thermal gun serta melakukan penyemprotan disinfektan di lingkungan kerja UT secara berkala. Yang maish harus menjadi perhatian adalah masing-masing individu yang beribadah di musholla harus membawa sajadah masing-masing, namun secara prosentase masih tinggi yaitu sebesar $64,1 \%$. Karena di UPBJJ UT Samarinda tidak ada bis UT maka poin untuk menyemprot cairan disinfektan tidak dapat dilakukan. Hal ini dapat menjelaskan bahwa untuk tingkat kepatuhan dan kesadaran pekerja di lingkungan UPBJJ UT Samarinda dalam menerapkan Protokol Kesehatan dinilai cukup baik.

\section{Faktor-faktor penyebab yang memengaruhi tingkat kesadaran dan kepatuhan hukum pekerja terhadap protokol kesehatan masa pandemi Covid-19 di UPBJJ UT Samarinda}

Kesadaran dan kepatuhan hukum pekerja di lingkungan UPBJJ UT Samarinda terhadapm Protokol kesehatan sangat dipengaruhi oleh beberapa faktor, yaitu sebagai berikut.

1. Faktor hukum

Kesadaran dan kepatuhan hukum merupakan salah satu faktor penting dalam menerapkan aturan yang dibuat, kesadaran dan kepatuhan hukum memiliki suatu kaitan yang erat dengan hukum dimana suatu hukum atau aturan jika tidak didasarkan atas nilai kesadaran dan kepatuhan maka tidak akan ada kekuatan mengikat pada aturan tersebut.

Kebijakan Kementrian Kesehatan Republik Indonesia Nomor HK.01.07/MENKES/382/2020 Tentang Protokol Kesehatan bagi Masyarakat di tempat dan Fasilitas Umum dalam Rangka Pencegahan dan Pengendalian Corona Virus Disease 2019 (Covid-19), secara umum diikuti oleh seluruh pekerja yang ada di UPBJJ UT Samarinda, namun terkadang berdasarkan dari pengamatan yang dilakukan peneliti masih saja terjadi beberapa pelanggarang yang dilakukan seperti tidak memakai masker dan tidak menjaga jarak hal ini juga menjadi faktor yang memengaruhi kesadaran dan kepatuhan hukum pekerja dalam menerapkan protokol kesehatan masa pandemi dikarenakan aturan tersebut hanya sebatas upaya-upaya pencegahan dan penularan lebih luas melalui langkah-langkah protokol kesehatan yang telah diatur namun untuk penerapan sanksi tidak ada sebagai efek jera sehingga beberapa pihak yang tidak memiliki kesadaran dan kepatuhan hukum dalam penerapan protokol kesehatan masa 
pandemi masih sering melakukan pelanggaran-pelanggaran tersebut, karena nilai-nilai kesadaran dan kepatuhan hukum tidak serta merta di dasarkan atas sanksi namun efek dari mengabaikan aturan tersebutlah yang menjadi unsur penting seseorang bertindak lalai.

2. Faktor Saran dan Prasarana

Sarana dan prasarana merupakan salah satu faktor penunjang dari kesadaran dan kepatuhan hukum pekerja dalam melaksanakan protokol kesehatan. Sarana prasarana sendiri di UPBJJ UT Samarinda telah di persiapkan sedemikian rupa dengan disediakan fasilitas cuci tangan, menyediakan masker, pemeriksaan suhu tubuh dengan termogan penyediaan hand sanitaizer, pembatasan jarak hal ini sesuai dengan apa yang ada dalam aturan protokol kesehatan. Hal ini di terapkan guna dapat di patuhi oleh pekerja mengurangi resiko-resiko penyebaran. namun dari pengamatan peneliti hal ini dilakukan ketika awal-awal pandemi saja, saat ini salah satu sarana yang jarang digunakan adalah tempat cuci tangan karna dirasa sudah kurang layak dan pemeriksaan suhu tubuh dengan termogan. Kesadaran akan pentingnya mencuci tangan dan pemeriksaan suhu tubuh pada saat masuk kantor dirasa masih kurang dipatuhi oleh setiap pekerja.

3. Faktor Pengetahuan pekerja

Mengetahui apa itu Covid-19 sangatlah penting dimana dengan mengetahui bahaya yang ditimbulkan maka, masyarakat dalam hal ini pekerja dapat menyadari bagaimana dengan patuh dan menerapkan protokol kesehatan pekerja bisa tetap bekerja tanpa khawatir untuk tertular Covid-19 di luar maupun tempat kekerja. Dengan persepsi dan pengetahuan yang dimiliki, pekerja yang tidak mentaati protokol kesehatan dapat dibantu dan diberi penjelasan bahaya dari Covid-19, pengetahuan akan covid tidak muncul begitu saja, tetapi pengetahuan tersebut didapat dari berbagai informasi yang ada baik media masa, dari surat edaran ataupun fasilitas informasi publik lainnya.

Sosialisasi merupakan salah satu upaya yang dilakukan untuk menambah pengetahuan pekerja tentang Covid-19 dengan informasi yang jelas dan tepat dapat menyadarkan kita pentingnya mematuhi protokol kesehatan, dengan adanya sosialisasi dimaksudkan agar masyarakat dapat memahamin isi dari aturan-aturan yang telah ditetapkan tersebut, seperti yang telah disampaikan beberapa pekerja dari hasil wawancara secara langsung, para pekerja mengetahui apa itu Covid-19, mereka mengetahui aturan-aturan protokol kesehatan apa saya yang harus di patuhi.

\section{Upaya yang dilakukan untuk meningkatkan kesadaran dan kepatuhan hukum pekerja terhadap protokol kesehatan masa pandemi Covid-19 di UPBJJ UT Samarinda}

Dalam meningkatkan kesadaran dan kepatuhan hukum pekerja terhadap protokol kesehatan masa pandemi Covid-19 upaya yang dilakukan UPBJJ UT Samarinda berdasarkan faktor-faktor yang memengaruhinya, yaitu sebagai berikut.

1. Segi Hukum

Untuk terus meningkatkan nilai-nilai kesadaran dan kepatuhan hukum atas protokol kesehatan UPBJJ UT Samarinda upaya yang perlu dilakukan adalah menerapkan kebijakan yang tepat dan diawasi untuk tetap melakukan prilaku disiplin di dalam lingkungan UPBJJ UT Samarinda, menegur secara tegas setiap karyawan yang terindikasi melanggar Protokol Kesehatan dengan memberikan kebijakan-kebijakan yang dirasa sesuai.

2. Segi sarana dan prasarana

Upaya yang dilakukan pada Sarana dan prasarana yang ada diUPBJJ UT Samarinda di gunakan secara Optimal, perbaikan fasilitas tempat cuci tangan penyediaan handsanitizer, serta petugas pengecekan suhu tubuh selalu ada ketika pekerja akan memasuki tempat kerja, bannerbanner/ spanduk kecil tentang informasi seputar pencegahan Covid-19 di letakkan pada tempat yang strategis. Serta penyemprotan cairan antiseptik secara berkala di lingkungan UPBJJ UT 
Samarinda. Yang terpenting lagi adalah melakukan tarcing kesehatan kepada setiap pekerja rutin setiap bulannya.

3. Dari segi pengetahuan

Upaya yang dilakukan yaitu dengan cara selalu mensosialisasikan aturan-aturan baru Covid19, memberikan informasi terbaru seputar penyebaran Covid-19, memberikan pengarahan rutin kepada pekerja serta motivasi yang diharapkan dapat meningkatkan kesadaran dan kepatuhan pekerja dalam menerapkan protokol kesehatan. Serta penjelasan pentingnya pengawasan terhadap setiap kegiatan yang dilakukan oleh pekerja agar tidak bekerumun.

\section{Simpulan}

Kesadaran dan kepatuhan hukum pekerja terhadap protokol kesehatan masa Covid-19 di UPBJJ UT Samarinda ini dinilai cukup baik dilihat dari kasus yang terjadi selama masa pandemi hanya 2 orang pekerja yang terkonfirmasi positif terpapar Covid-19. Faktor-faktor penyebab yang memengaruhi tingkat kesadaran dan kepatuhan hukum pekerja terhadap protokol kesehatan masa pandemi Covid-19 di UPBJJ UT Samarinda, a) Faktor hukum, yaitu aturan dalam protokol kesehatan tidak memiliki sanksi untuk memberikan efek jera bagi yang melanggar protokol kesehatan sehingga masih ada beberapa pelanggaran dalam menerapkan protokol Kesehatan, b) Faktor saran dan prasarana, dalam menerapkan protokol kesehatan sarana dan prasana di UPBJJ UT Samarinda ada beberapa yang tidak digunakan secara optimal, seperti tempat cuci tangan dan pengecekan suhu tubuh. Faktor pengetahuan pekerja, hampir seluruh pekerja di UPBJJ UT Samarinda memiliki pengetahuan tentang Covid-19 yang diperoleh baik dari tempat kerja maupun media masa. Upaya yang dilakukan untuk meningkatkan kesadaran hukum pekerja terhadap protokol kesehatan masa pandemi Covid-19 di UPBJJJ UT Samarinda yaitu, a) Faktor Hukum, menerapkan kebijakan yang tepat dimasa pandemi, menegur secara tegas pekerja yang melanggar protokol Kesehatan, b) Faktor Sarana dan Prasarana, yaitu dengan mengoptimalkan sarana dan prasarana penunjang protokol kesehatan serta melakukan tracing kesehatan kepada seluruh pekerja di UPBJJ UT Samarinda. Kemudian dari segi pengetahuan, yaitu UPBJJ UT Samarinda memberikan sosialisasi tentang Covid19 serta melakukan penjelasan pentingnya pengawasan setiap kegiatan yang dilakukan.

\section{Daftar Pustaka}

Hardijan Rusli, 2003, Hukum Ketenagakerjaan, Jakarta, Ghalia Indonesia,.

R. Otje Salman Soemodiningrat, 2009, Filsafat Hukum (Perkembangan dan Dinamika Masalah, Refika Aditama, Bandung.

Keputusan Menteri Kesehatan RI Nomor HK.01.07/MENKES/382/2020 Tentang Protokol Kesehatan bagi Masyarakat di tempat dan Fasilitas Umum dalam Rangka Pencegahan dan Pengendalian Corona Virus Disease 2019 (Covid-19) Tahun 2020.

Rachmat Saleh, 2004, Studi Empiris Ketepatan Waktu Pelaporan Keuangan Perusahaan Manufaktur di Bursa Efek Jakarta, Balai Pustaka, Jakarta.

Rahardjo Satjipto, 1991, Ilmu Hukum, Citra aditya Bakti,Edisi Revisi, Bandung.

Soerjono Soekanto, 1982, Kesadaran Hukum Dan Kepatuhan Hukum, Edisi Pertama, CV. Rajawali, Jakarta.

Subri Mulyadi, 2012, Ekonomi Sumber Daya Manusia dalam Perspektif Pembangunan, Rajawali Pers,Jakarta.

Yos Johan Utama, 2018, Hukum Administrasi Negara, Universitas Terbuka, Tangerang Selatan.

Undang-Undang Republik Indonesia Nomor 13 Tahun 2003 Tentang Ketenagakerjaan.

Undang-Undang Republik Indonesia 21 Tahun 2000 Tentang Serikat Pekerja/ Serikat Buruh.

Surat Edaran Menteri Pendayagunaan Aparatur Negara Dan Reformasi Birokrasi Nomor 58 Tahun 2020 Tentang Sistem Kerja Pegawai Aparatur Sipil Negara Dalam Tatanan Normal Baru. 
Peraturan Rektor Universitas Nomor: 721 Tahun 2020 tentang Kebijakan Layanan Pendidikan Universitas Terbuka dalam Situasi Pandemi Covid 19 Semester 2020/21.2 (2020.2) Tahun 2020.

\section{ARTIKEL}

Dody Saputra Simanjuntak, "Kesadaran Hukum Sivitas Akademika dalam Berlalu Lintas di Lingkungan Fakultas Hukum Universitas Riau” (JOM Fakultas Hukum Volum 3 Nomor 2 Oktober 2016.

\section{LINK}

https://kbbi.web.id/badan diakses tanggal 14 Maret 2021.

https://www.cnnindonesia.com/nasional/20200918203843-20-548254/klaster-besar-perkantorancorona-buah-pahit-salah-prioritas, diakses 19 februari 2021

Pengelola web kemdikbud https://www.kemdikbud.go.id/main/blog/2020/06/panduanpenyelenggaraan-pembelajaran-pada-tahun-ajaran-dan-tah, diakses 19 februari 2021

https://news.detik.com/berita/d-5340410/grafik-corona-mingguan-di-ri-kasus-positif-kematianmeningkat-drastis, diakses 19 Februari 2021 